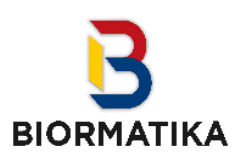

BIORMATIKA
BIORMATIKA

Jurnal Ilmiah Fakultas Keguruan dan Ilmu Pendidikan

http://ejournal.unsub.ac.id/index.php/FKIP/

\title{
Upaya Pengendalian Berat Badan Ideal (BMI) melalui Kegiatan Perintah Harian Sifat Tetap (PHST) Taruna Sekolah Tinggi Ilmu Pelayaran
}

\author{
April Gunawan Malau', Prihartanta ${ }^{2}$, Dedy Kurniadi ${ }^{3}$, Imam Fahcruddin ${ }^{4}$ \\ Sekolah Tinggi Ilmu Pelayaran Jakarta \\ Aprilgunawan22@gmail.com
}

\begin{tabular}{l} 
Info Artikel \\
\hline Sejarah Artikel: \\
Diterima Agustus 2019 \\
Disetujui September 2019 \\
Dipublikasikan September 2019
\end{tabular}

\begin{abstract}
Abstrak
Kebugaran jasmani sangat diperlukan taruna untuk menunjang kesiapan dalam menghadapi dunia kerja, terutama sektor pelayaran. Dengan menetapkan kegiatan perintah harian sifat tetap (PHST) diharapkan dapat mengendalikan berat badan ideal taruna. Penelitian ini bertujuan untuk mendeskripsikan berat badan ideal taruna Sekolah Tinggi Ilmu Pelayaran serta upaya pengendaliannya melalui kegiatan PHST. Metode yang digunakan adalah deskriptif kuantitatif. Dari hasil penelitian diperoleh taruna laki-laki semester III dan VII tidak ada yang masuk dalam kategori kurus, kategori normal sebanyak 407 orang, kategori kegemukan sebanyak 369 orang, kategori obesitas sebanyak 53 orang. Taruna perempuan semester III dan VII untuk kategori kurus sebanyak 5 orang, kategori normal sebanyak 54 orang, kategori kegemukan sebanyak 8 orang dan kategori obesitas sebanyak 12 orang. Upaya pengendalian BMI untuk taruna kategori gemuk dan obesitas melalui PHST adalah kegiatan push up, sit up, back lift, lari, mengangkat barbel, renang dan sterling.
\end{abstract}

Kata kunci: berat badan, ideal, perintah harian, taruna 
semester female cadets for the thin category were 5 people, the normal category was 54 people, the obesity category were 8 people and the obesity category were 12 people. The effort to control BMI for obese and obese categories through PHST is push up, sit up, back lifts, run, barbell lifts, swimming and sterling.

Keywords: weight, ideal, daily orders, cadets

ISSN 2580-6335 (online)

ISSN 2461-3961 (cetak)

\section{PENDAHULUAN}

Sekolah Tinggi Ilmu Pelayaran adalah perguruan tinggi negeri yang menyelenggarakan pendidikan akademik dan vokasi dalam lingkup bidang pelayaran. Pendidikan vokasi yang mempersiapkan peserta didik/taruna/i untuk memiliki keahlian terapan dalam ilmu pelayaran sedangkan pendidikan akademik adalah perguruan tinggi program sarjana yang diarahkan pada penguasaan disiplin ilmu pelayaran.

Sekolah Tinggi Ilmu Pelayaran memiliki sistem pendidikan boarding school dimana peserta taruna melakukan semua kegiatan pendidikan dan kegiatan di luar pendidikan di lingkungan kampus. Selain tuntutan kualitas dalam bidang pendidikan, peserta taruna juga dituntut memiliki kebugaran jasmani dan penampilan fisik yang baik.

Kebugaran jasmani sangat diperlukan oleh peserta taruna, karena faktor tersebut sangat menunjang hasil aktivitas yang dilakukan. Maka dari itu kebugaran jasmani yang berkaitan dengan diri seorang peserta taruna merupakan aspek penting yang harus dijaga. Untuk mempertahankan kebugarannya, taruna di tuntut dapat mengatur pola hidupnya dengan teratur berolahraga, dengan begitu taruna akan memiliki tingkat kebugaran jasmani yang diinginkan sehingga dapat memaksimalkan pikiran dan tenaganya untuk beraktivitas.

Penampilan fisik adalah segala sesuatu yang berhubungan dengan penampilan luar seseorang yang mudah diamati dan dinilai oleh orang sekelilingnya. Penampilan fisik secara disadari atau tidak, dapat menimbulkan respon atau tanggapan tertentu dari orang lain. Penampilan fisik taruna yang menarik sudah dijadikan sebagai syarat resmi. Beberapa lapangan pekerjaan telah menuntut para pegawainya untuk berpakaian dan berpenampilan baik. Peran dari penampilan fisik adalah untuk memberikan deskripsi atau gambaran singkat akan diri orang tersebut.

Dalam hal ini kebugaran jasmani seorang taruna dapat dilihat dari penampilan fisiknya. Apabila seorang taruna memiliki penampilan fisik yang baik maka dapat dinyatakan ia memiliki kebugaran jasmani yang baik. Pada dasarnya dalam menjaga penampilan fisik yang baik dapat dilakukan dengan berbagai macam latihan jasmani atau olahraga.

Kondisi saat ini, aktifitas taruna didalam lingkungan kampus tergolong maksimal tetapi bukan dalam kegiatan olahraga yang teratur yang dapat menunjang kebugaran jasmaninya yang dapat dilihat dari penampilan fisik. Hal ini dapat kita lihat dari kegiatan PHST (Perintah Harian Sifat Tetap) yang ada. 
Berikut ini disajikan tabel kegiatan PHST taruna tahun 2018.

Tabel 1. Kegiatan PHST Taruna Tahun 2018

\begin{tabular}{|c|c|}
\hline WAKTU & JENIS KEGIATAN \\
\hline $04.00-04.30$ & $\begin{array}{l}\text { Bel Bangun Pagi, Olahraga } \\
\text { Pagi }\end{array}$ \\
\hline $04.30-05.50$ & $\begin{array}{l}\text { Shalat Subuh, } \\
\text { Membersihkan kamar, } \\
\text { Dormitory, Mandi Pagi }\end{array}$ \\
\hline $05.50-06.00$ & Persiapan Makan Pagi \\
\hline $06.00-06.20$ & Makan Pagi \\
\hline $06.20-06.30$ & Persiapan Apel Pagi \\
\hline $06.30-07.00$ & Apel Pagi \\
\hline $07.00-07.20$ & $\begin{array}{l}\text { Pengarahan dan Evaluasi } \\
\text { Kegiatan }\end{array}$ \\
\hline $07.20-07.30$ & Persiapan Menuju Kelas \\
\hline $07.30-10.00$ & Kegiatan Perkuliahan \\
\hline $10.00-10.15$ & Istirahat \\
\hline $10.15-11.50$ & Kegiatan Perkuliahan \\
\hline $11.50-12.20$ & Sholat Dzuhur \\
\hline $12.20-12.45$ & Makan Siang \\
\hline $12.45-13.00$ & Persiapan Menuju Kelas \\
\hline $13.00-15.00$ & Kegiatan Perkuliahan \\
\hline $15.00-15.30$ & Sholat Ashar dan Istirahat \\
\hline $15.30-17.15$ & $\begin{array}{l}\text { Apel Devisi Jaga Taruna, } \\
\text { Olahraga Sore, Soft Skill } \\
\text { serta Kegiatan } \\
\text { Ekstrakurikuler lainnya dan } \\
\text { Pembinaan Tim TC } \\
\text { Apel Devisi Jaga Taruna, } \\
\text { General Cleaning dan } \\
\text { Olahraga Sore (Hari Rabu) }\end{array}$ \\
\hline $17.15-18.00$ & $\begin{array}{l}\text { Mandi dan Persiapan Sholat } \\
\text { Magrib }\end{array}$ \\
\hline $18.00-18.20$ & Sholat Magrib \\
\hline $18.20-18.35$ & Persiapan Makan Malam \\
\hline $18.35-18 . .55$ & Makan Malam \\
\hline $18.55-19.25$ & Sholat Isya \\
\hline $19.25-20.00$ & $\begin{array}{l}\text { Kebersihan kamar dan } \\
\text { Persiapan apel malam }\end{array}$ \\
\hline $20.00-20.45$ & Apel Malam \\
\hline
\end{tabular}

20.45-22.00 Belajar Malam

22.00-04.00 Istirahat Malam

Dari Tabel 1 terlihat bahwa semua kegiatan rata-rata bersifat akademik dan kegiatan olahraga dilakukan hanya di pagi hari saja dan satu jam pada sore hari. Kegiatan olahraga yang dilakukan juga hanya berdasarkan hobi terhadap bidang olahraga yang telah di fasilitasi antara lain sepak bola, bola voli, futsal, badminton, basket, tennis meja dan renang. Padahal dalam menjaga kebugaran jasmani untuk mendukung penampilan taruna diperlukan latihan olahraga yang terstruktur dan teratur.

Dari uraian diatas, peneliti tertarik untuk mengkaji Pengendalian Berat Badan Ideal (BMI) melalui Kegiatan Perintah Harian Sifat Tetap (PHST) Taruna Sekolah Tinggi Ilmu Pelayaran. Dengan menetapkan kegiatan perintah harian sifat tetap (PHST) diharapkan dapat mengendalikan berat badan ideal taruna. Penelitian ini bertujuan untuk mendeskripsikan berat badan ideal taruna Sekolah Tinggi Ilmu Pelayaran serta upaya pengendaliannya melalui kegiatan PHST.

Indeks Massa Tubuh atau Body Mass Index merupakan sebuah angka kalkulasi dari berat badan dan tinggi badan seseorang. Indeks massa tubuh memberikan indikator yang bisa dipercaya mengenai kegemukan tubuh bagi kebanyakan orang dan pengukuran ini digunakan untuk screening kategori berat badan yang mungkin bisa mengarah atau mendorong serta berpengaruh pada gangguan atau masalah kesehatan.

Dengan screening dini dan mengetahui BMI, anda dapat mengontrol berat badan anda dengan pola dan gaya hiup sehat sehingga terhindar dari masalah, gangguan kesehatan atau penyakit-penyakit 
maupaun gangguan mental dan psikologis yang berhubungan dengan berat badan. Dibawah ini adalah tabel klasifikasi atau pengelompokan BMI dari WHO (World Health Organization).

Tabel 2. Pengelompokan BMI dari WHO

\begin{tabular}{cc}
\hline Arti & BMI \\
\hline Berat badan normal & $19-24,9$ \\
\hline Kelebihan berat badan & $25-29,9$ \\
\hline Obesitas derajat I & $30-34,9$ \\
\hline Obesitas derajat II & $35-39,9$ \\
\hline Obesitas derajat III & $\geq 40$ \\
\hline
\end{tabular}

Berikut ini adalah tabel klasifikasi atau pengelompokan BMI berdasarkan umur menurut National Research Council (NRC) tahun 1989.

Tabel 3. Pengelompokan BMI berdasarkan umur

\begin{tabular}{cc}
\hline Umur & BMI \\
\hline 19-24 tahun & $19-24$ \\
\hline 25-34 tahun & $20-25$ \\
\hline 35-44 tahun & $21-26$ \\
\hline 45-54 tahun & $22-27$ \\
\hline 55-64 tahun & $23-28$ \\
\hline Lebih dari 65 tahun & $24-29$
\end{tabular}

Masalah yang nyata adalah pada olahragawan. Pada olahragawan otototot tubuh cenderung lebih besar dan otot tubuh mempunyai lebih banyak berat daripada lemak tubuh. Sehingga mereka mempunyai nilai Indeks Massa Tubuh yang tinggi pada saat pengukuran, tapi hal ini tidak berarti bahwa ini adalah masalah kesehatan.

BMI (Body Mass Index) atau Indeks Massa Tubuh adalah salah satu cara yang dipergunakan untuk mengukur kenormalan berat badan seseorang berdasarkan ketinggian tubuhnya. Dalam Bahasa Indonesia, Body Mass Index (BMI) disebut dengan Indeks Massa Tubuh atau disingkat dengan IMT.

Berat badan yang berlebihan disebut dengan Obesitas (Kegemukan). Obesitas dapat meningkatkan risiko timbulnya berbagai penyakit seperti Diabetes (kencing manis), Serangan Jantung, Hipertensi, Asam urat, kolesterol tinggi dan juga Sleep Apnea yaitu kesulitan tidur nyenyak karena gangguan pernapasan. Oleh karena itu, mengetahui Indeks BMI tubuh kita merupakan hal yang penting agar kita dapat menjaga berat badan kita selalu pada kondisi yang normal sehingga dapat menurunkan risiko timbulnya penyakit-penyakit yang dikarenakan oleh Obesitas ini.

Rumus untuk menghitung BMI atau Indeks Massa Tubuh adalah

$$
B M I=\frac{\text { Berat Badan }(\mathrm{kg})}{{\text { Tinggi } \operatorname{Badan}^{2}(\mathrm{~m})}}
$$

Berikut ini adalah Tabel BMI yang dibagi menjadi 2 (dua) kategori yaitu kategori BMI untuk Laki-laki dan kategori BMI untuk Perempuan.

Tabel 4. Kategori BMI untuk laki-laki

\begin{tabular}{cc}
\hline Nilai BMI & Kategori \\
\hline$<17$ & Kurus \\
\hline $17-23$ & Normal \\
\hline $23-27$ & Kegemukan \\
\hline$>27$ & Obesitas \\
\hline
\end{tabular}

Tabel 5. Kategori BMI untuk perempuan

\begin{tabular}{cc}
\hline Nilai BMI & Kategori \\
\hline$<18$ & Kurus \\
\hline $18-25$ & Normal \\
\hline
\end{tabular}




\begin{tabular}{cc}
\hline $25-27$ & Kegemukan \\
\hline$>27$ & Obesitas
\end{tabular}

Kegemukan atau obesitas adalah suatu kondisi medis berupa kelebihan lemak tubuh yang terakumulasi sedemikian rupa sehingga menimbulkan dampak merugikan bagi kesehatan, yang kemudian menurunkan harapan hidup dan/atau meningkatkan masalah kesehatan. Seseorang dianggap menderita kegemukan (obese) bila Indeks Massa Tubuh (IMT), yaitu ukuran yang diperoleh dari hasil pembagian berat badan dalam kilogram dengan kuadrat tinggi badan dalam meter, lebih dari $30 \mathrm{~kg} / \mathrm{m}^{2}$.

Kegemukan meningkatkan peluang terjadinya berbagai macam penyakit, khususnya penyakit jantung, diabetes tipe 2, apnea tidur obstruktif, kanker tertentu, osteoartritis dan asma. Kegemukan sangat sering disebabkan oleh kombinasi antara asupan energi makanan yang berlebihan, kurangnya aktivitas fisik, dan kerentanan genetik, meskipun sebagian kecil kasus terutama disebabkan oleh gen, gangguan endokrin, obat-obatan atau penyakit psikiatri.

Hanya sedikit bukti yang mendukung pandangan bahwa orang yang gemuk makan sedikit namun berat badannya bertambah karena metabolisme tubuh yang lambat; ratarata orang gemuk mengeluarkan energi yang lebih besar dibandingkan orang yang kurus karena dibutuhkan energi untuk manjaga massa tubuh yang lebih besar.

Kegemukan adalah penyebab kematian yang dapat dicegah paling utama di dunia, dengan prevalensi pada orang dewasa dan anak yang semakin meningkat, sehingga pihak berwenang menganggap kegemukan sebagai salah satu masalah kesehatan masyarakat paling serius pada abad 21. Kegemukan umumnya merupakan stigma di dunia modern (khususnya di Dunia barat), meskipun pada suatu waktu dalam sejarah, kegemukan secara luas dianggap sebagai simbol kekayaan dan kesuburan, dan masih dianggap demikian di beberapa bagian di dunia hingga sekarang.

\section{METODE}

Desain penelitian yang digunakan dalah deskriptif kuantitatif. Populasi dalam penelitian ini adalah seluruh taruna Sekolah Tinggi Ilmu Pelayaran. Sampel yang diambil sebanyak 908 taruna. Data yang digunakan adalah BMI taruna.

\section{HASIL DAN PEMBAHASAN}

Berdasarkan Tabel 1, sesuai dengan Perintah Harian Sifat Tetap untuk menjaga kebugaran jasmani taruna/i dengan kegiatan olah raga secara rutin dengan waktu 30 menit yaitu pada pagi hari dan untuk kegiatan olah raga sore selama 1 jam berdasarkan hobi menurut cabang olah raga yang ditentukan. Adapun keikutsertaan taruna semester III dan VII dalam ekstrakulikuler olah raga disajikan dalam tabel berikut.

Tabel 6. Rekapitulasi Keikutsertaan

Taruna Semester III dan VII untuk kegiatan ekstrakulikuler

\begin{tabular}{ccc}
\hline No & $\begin{array}{c}\text { Jenis } \\
\text { Olahraga }\end{array}$ & $\begin{array}{c}\text { Jumlah } \\
\text { Taruna/i }\end{array}$ \\
\hline 1 & Futsal & 37 \\
\hline 2 & Sepak Bola & 23 \\
\hline 3 & Volly & 27 \\
\hline 4 & Basket & 17 \\
\hline 5 & Selam & 29 \\
\hline 6 & Dayung & 9 \\
\hline 7 & Selam & 9 \\
\hline 8 & Badminton & 46 \\
\hline
\end{tabular}




\begin{tabular}{ccc}
\hline 9 & Tennis Meja & 6 \\
\hline 10 & Atletik & 2 \\
\hline 11 & Renang & 42 \\
\hline
\end{tabular}

Berdasarkan Tabel 6 terlihat bahwa dari 11 cabang olah raga berdasarkan hobi yang dimiliki oleh taruna semester VII diikuti oleh 239 taruna dari 372 taruna. Pelaksanaan kegiatan olah raga sesuai dengan hobi taruna semester III dan VII. Kegiatan ekstrakulikuler dilakukan setiap hari Senin dan Rabu dalam satu minggu dengan waktu kegiatan adalah 1 jam yang dimulai dari jam 16.00 WIB sampai dengan 17.00 WIB.

Selanjutnya, data BMI taruna semester III disajikan dalam tabel berikut.

\begin{tabular}{llll}
\hline 27 & Obesitas & 12 & 15.19
\end{tabular}

Berdasarkan Tabel 8 diatas setelah dilakukan pengukuran BMI taruni semester III yang berjumlah sebanyak 79 taruni masih terdapat $10,13 \%$ atau 8 taruni dikategori kegemukan dan 15,19 $\%$ atau 12 taruni dikategorikan obesitas. Kemudian untuk semester VII disajikan dalam tabel berikut.

Tabel 9. Data BMI Taruna Semester VII

\begin{tabular}{cccc}
$\begin{array}{c}\text { Nilai } \\
\text { BMI }\end{array}$ & Kategori & JML & \% \\
\hline$<18$ & Kurus & 13 & 3.95 \\
\hline $18-25$ & Normal & 197 & 59.88 \\
\hline $25-27$ & Kegemukan & 48 & 14.59 \\
\hline$>27$ & Obesitas & 51 & 15.50 \\
\hline
\end{tabular}

Berdasarkan Tabel 9 diatas setelah

Tabel 7. Data BMI Taruna Semester III

$\begin{array}{llll}\text { Nilai } & \text { Kategori } & \text { JML } & \% \\ \text { BMI } & & \end{array}$
dilakukan pengukuran BMI taruna semester VII yang berjumlah sebanyak 329 taruna masih terdapat $14,59 \%$ atau sebanyak 48 taruna dikategori

\begin{tabular}{ccccc}
$<17$ & Kurus & 0 & $\begin{array}{c}329 \text { taruna masih terdapat } \\
\text { sebanyak } 48 \text { taruna }\end{array} \begin{array}{r}\text { takategori } \\
\text { dikate }\end{array}$ \\
\hline $17-23$ & Normal & 407 & 49.09 kegemukan dan $15,50 \%$ sebanyak 51 \\
\hline $23-27$ & Kegemukan & 369 & 44.51 taruna dikategorikan obesitas.
\end{tabular}

$>27 \quad$ Obesitas $\quad 53 \quad 6.39$ Tabel 10. Data BMI Taruni Semester VII

Berdasarkan Tabel 7 diatas setelah dilakukan pengukuran BMI taruna semester III yang berjumlah sebanyak 829 taruna masih terdapat $44,51 \%$ atau 369 taruna dikategori kegemukan dan $6,39 \%$ atau 53 taruna dikategorikan obesitas.

Tabel 8. Data BMI Taruni Semester III

$\begin{array}{llll}\text { Nilai } & \text { Kategori JML \% } \\ \text { BMI } & & \end{array}$

$\begin{array}{llll}\text { Nilai } & \text { Kategori } & \text { JML } & \% \\ \text { BMI } & \end{array}$

\begin{tabular}{cccc}
\hline$<18$ & Kurus & 0 & 0 \\
\hline $18-25$ & Normal & 30 & 69.77 \\
\hline $25-27$ & Kegemukan & 9 & 20,93 \\
\hline$>27$ & Obesitas & 4 & 9.30 \\
\hline
\end{tabular}

Berdasarkan Tabel 10 diatas setelah dilakukan pengukuran dengan menggunakan metode BMI untuk setiap

\begin{tabular}{cccc}
$<18$ & Kurus & 5 & 6.33 taruni semester VII yang berjumlah \\
\hline $18-25$ & Normal & 54 & 68.35 sebanyak 43 taruni masih terdapat 20,93 \\
\hline $25-27$ & Kegemukan & 8 & $10.13 \%$ atau sebanyak 9 taruni dikategori
\end{tabular}


kegemukan dan 9,30\% atau sebanyak 4 taruni dikategorikan obesitas.

Mengacu dengan data hasil pengukuran BMI dapat diambil persentase kumulatif dari 908 taruna masih terdapat $33,90 \%$ atau sebanyak 434 taruna yang terkategori kegemukan dan $9,37 \%$ atau sebanyak 120 taruna terkategori obesitas.

Kondisi ini harus cepat diantisipasi dengan melakukan kegiatan olah raga yang mendukung tingkat kebugaran jasmani dalam menjaga keidealan tubuh taruna. Sehubungan dengan padatnya kegiatan taruna yang tertuang dalam PSHT, menjadi sangat sulit jika harus menambah jumlah jam olah raga taruna. Oleh sebab itu, yang perlu ditekankan adalah meningkatkan bobot olah raga. Jadi dalam waktu 1 jam tidak diisi dengan kegiatan ringan-ringan saja, tetapi penambahan aktivitas fisik yang dapat menyebabkan tubuh taruna menjadi lebih ideal.

Hal ini dapat dilakukan dengan melaksanakan kegiatan olah raga yang kontinue berupa latihan kebugaran jasmani dengan melaksanakan kegiatan olah raga setiap hari sebagai berikut:

a. Latihan Kekuatan

Kekuatan adalah kemampuan otot untuk melakukan kerja yang berfungsi membangkitkan ketegangan terhadap suatu tahanan. Otot-otot yang kuat dapat melindungi persendian disekelilingnya dan mengurangi kemungkinan terjadinya cedera karena aktifitas fisik. Oleh karena itu, otot-otot perlu dilatih untuk memiliki kekuatan. Bentukbentuk latihan kekuatan misalnya push up, sit up dan back lift.

b. Latihan kecepatan

Latihan kecepatan dengan melakukan latihan lari cepat yang bertujuan untuk melatih kecepatan gerak seseorang. Latihan cepat jarak 40 meter dan 60 meter dapat dilakukan dengan cara berikut ini.
1. Berdiri dibelakang garis start dengan sikap badan berdiri tegak dan kedua kaki terbuka.

2. Kedua tangan berada di samping badan dalam sikap siap berlari.

3. Kaki lari di tempat, paha diangkat, tangan mengikuti gerakan lari, semakin lama semakin cepat.

4. Setelah diberi aba-aba, lari secepat-cepatnya menempuh jarak 40 meter atau 60 meter.

c. Latihan daya tahan

Latihan daya tahan dibedakan menjadi dua, yaitu daya tahan otot dan daya tahan jantung dan paru-paru.

d. Latihan daya tahan jantung dan paruparu

Latihan daya tahan jantung dan paru-paru adalah latihan yang dapat meningkatkan dan mengembangkan daya tahan jantung dan paru-paru. Latihan tersebut meliputi lari dan renang jarak jauh, interval training, serta latihan apapun yang memaksa tubuh bekerja dalam waktu lebih dari 6 menit. Interval training adalah suatu sistem latihan yang diselingi waktu untuk istirahat. Latihan ini dapat berupa lari (interval running) dan renang (inteval swimming). Latihan ini penting untuk program latihan secara keseluruhan. Dalam latihan interval training terdapat beberapa faktor yang harus di perhatikan. Faktor-faktor tersebut antara lain lamanya latihan, intensitas latihan, ulangan latihan, masa istirahat setelah setiap latihan, jarak yang di tempuh, dan kecepatan melakuklan latihan.

e. Latihan kelenturan (fleksibelitas)

Kelenturan adalah jangkauan gerakan yang dapat dilakukan tangan, kaki, kulit,dan jaringan tubuh yang berhubungan. Kondisi sendi membatasi 
jangkauan gerakan, begitu juga dengan lemak tubuh yang berlebihan. Cidera terjadi bila tangan dan kaki dipaksa bergerak melebihi jangkauan normalnya.

\section{KESIMPULAN}

Adapun kesimpulan dalam penelitian ini diantaranya yaitu taruna laki-laki semester III dan VII tidak ada yang masuk dalam kategori kurus, kategori normal sebanyak 407 orang, kategori kegemukan sebanyak 369 orang, kategori obesitas sebanyak 53 orang. Taruna perempuan semester III dan VII untuk kategori kurus sebanyak 5 orang, kategori normal sebanyak 54 orang, kategori kegemukan sebanyak 8 orang dan kategori obesitas sebanyak 12 orang. Aktivitas olah raga yang perlu ditambahkan diantaranya:

1. Latihan kekuatan dengan cara push up, sit up dan back lift.

2. Latihan kecepatan dengan cara lari 40 meter dan 60 meter.

3. Latihan daya tahan dengan cara mengangkat barbel.

4. Latihan daya tahan jantung dan paru-paru dengan cara renang jarak jauh.

5. Latihan kelenturan (fleksibelitas) dengan cara stresing yang teratur.

\section{DAFTAR PUSTAKA}

Bompa, T. O. (1994). Theory and Methodology of Training: The Key to Athletics Performance. Dubuque: Kendall/Hunt Publishing Company.

Emma, S. W. (1997). Cara Amandan Efektif Menurunkan Berat Badan. Jakarta: Gramedia

Getchell, B. (1979). Physical Fitness A Way of Life.New York: John Willey and Sons. Inc.
Husaini (1996). "Energy dan Berat Badan Usia Lanjut". Dalam Gizi Indonesia. Journal of The Indinesian Nutrition Association. Jakarta: Persagi. Vol. XVI. No. 12.

Kuntaraf, J. dan Kuntaraf, K. L. (1982). Olahraga Sumber Kesehatan. Jakarta: Publishing Housse. Pustaka Utama.

Sarwono (2001). "Kebugaran Jasmani Mahasiswa Hubungannya dengan Indek Masa Tubuh dan Kadar Hemoglobin".(Studi pada Jurusan POK FKIP UNS). Jurnal Penelitian Pendidikan Paedagigia.FKIP-UNS.

Sharkey, B. J. (2003). Fitness and Health. Jakarta: PT Raja Grafindo Persada. Sumosardjuno, S. (1989). Petunjuk Praktis Kesehatan Olahraga. Jakarta: Pustaka Karya Grafita Utama.

Zainudin, M. (1988). Metodologi Penelitian. Surabaya: Fakultas Pascasarjana Universitas Airlangga. 